\title{
Olga Dzilińska
}

\section{Reforma polityki i systemu gwarantowania depozytów w Unii Europejskiej}

\begin{abstract}
Streszczenie
System gwarantowania depozytów jest istotnym elementem sieci bezpieczeństwa finansowego, który w Unii Europejskiej przechodzi obecnie istotną reformę w związku z tworzeniem unii bankowej. $Z$ tego względu istotne jest przedstawienie możliwych modeli docelowych, ich adekwatności w odniesieniu do założonych przez reformę celów, a także analiza uwarunkowań, które zadecydowały o wyłonieniu tego modelu, który jest wdrażany. Rozważenia wymaga również projektowana konstrukcja i jej potencjał w zakresie eliminacji dysfunkcji systemu, zarówno tych uwzględnionych przez unijnego prawodawcę, jak i inherentnie wpisanej w istnienie gwarancji depozytów pokusy nadużycia.
\end{abstract}

Słowa kluczowe: system gwarantowania depozytów, unia bankowa, sieć bezpieczeństwa finansowego, pokusa nadużycia, arbitraż regulacyjny, uwarunkowanie ścieżką.

\section{The reform of the policy and the system of deposit guarantee in the European Union}

\begin{abstract}
A deposit guarantee scheme is a crucial element of the financial safety network, which is currently undergoing a major reform in the European Union due to the process of the creation of the banking union. Therefore, it is important to present a variety of the possible target models, their adequacy in relation to the objectives set in the reform as well as to analyse the conditions which contributed to the choice of the one that is being implemented. What also needs to be addressed is the issue of the proposed model along with its potential to eliminate systemic dysfunctions, involving those addressed by the EU legislator as well as the moral hazard inherently present in the mere concept of a deposit guarantee scheme.
\end{abstract}

Keywords: deposit guarantee scheme, banking union, safety net, moral hazard, regulatory arbitrage, path dependence. 
Dla zapewnienia stabilności finansowej rozumianej jako zdolność systemu finansowego do wypełniania swoich funkcji w sposób ciągły i efektywny, nawet w wypadku wystąpienia nieoczekiwanych i niekorzystnych zaburzeń o znacznej skali ${ }^{1}$, konieczne są oprócz instrumentów nadzorczych również mechanizmy pomocowe i instytucje gwarancyjne. Kryzys 2007+ przypomniał, że bez tych pierwszych trzeba sięgać wprost do kieszeni podatników w razie wystąpienia poważniejszych szoków w systemie finansowym, a bez drugich - problemy jednego banku mogą relatywnie łatwo rozprzestrzenić się na cały sektor ze względu na dobrze znany mechanizm paniki bankowej (bank run). Dlatego schematy gwarantowania depozytów stają się coraz istotniejszym elementem sieci bezpieczeństwa finansowego (safety net). Wspólny system ochrony depozytów miał stać się jednym z podstawowych filarów unii bankowej, zaproponowanej przez przewodniczącego Rady Europejskiej w 2012 r. W toku realizacji reformy pierwotna koncepcja uległa jednak istotnemu przeobrażeniu i na wspólny system przyjdzie jeszcze Unii Europejskiej zaczekać.

Niniejsze opracowanie stanowi próbę naszkicowania procesu reformy systemu gwarantowania depozytów w UE, z uwzględnieniem wspomnianej zmiany podstawowego kierunku oraz architektury zastosowanych rozwiązań. W pierwszej części przedstawione zostaną perspektywy, jakie otwierało tworzenie unii bankowej, zaś $\mathrm{w}$ drugiej przeanalizowana zostanie konstrukcja przyjętego rozwiązania. W związku z powyższym, analiza będzie sięgać do osiągnięć teorii nowego instytucjonalizmu², żeby ocenić, czy reforma ma zdolność do wyeliminowania dysfunkcji, w które jest wymierzona (fragmentyzacji i arbitrażu regulacyjnego, konieczności wspierania systemu finansowego ze środków publicznych oraz zachwianego zaufania do systemu bankowego), i czy faktycznie wdraża lepsze rozwiązanie. Umiejscowienie problemu

1 Raport o stabilności systemu finansowego czerwiec 2009 r., red. P. Szpunar, Narodowy Bank Polski, Warszawa 2009, s. 3.

2 Nurt pojawił w naukach ekonomicznych w II poł. XX w. jako rozwinięcie ekonomii neoklasycznej, a zwłaszcza mikroekonomicznej teorii racjonalnego wyboru, w odpowiedzi na krytykę instytucjonalistów. Zastosowano neoklasyczną metodę indywidualizmu badawczego i założenie racjonalności jednostek do badania zjawisk społecznych i politycznych. Obecnie korzysta z dorobku różnych nauk społecznych (ekonomii, nauk politycznych, socjologii, prawa i antropologii) w badaniu instytucji rozumianych jako zaprojektowane przez człowieka ograniczenia, które kształtują interakcje społeczne (D.C. North, Institutions, Institutional Change and Economic Performance, Cambridge University Press, Cambridge 1990, s. 3).

$\mathrm{Na}$ gruncie nowego instytucjonalizmu istotne jest rozróżnienie między instytucjami, czyli formalnymi i nieformalnymi zasadami regulującymi interakcje, a organizacjami - mogącymi występować w roli podmiotów tych interakcji. D.C. North zilustrował różnicę przykładem boiska, na którym gracze (organizacje) podporządkowani są regułom rozgrywek (instytucje) w danej dyscyplinie sportu (D.C. North, J.J. Wallis, Integrating Institutional Change and Technical Change in Economic History: A Transaction Cost Approach, "Journal of Institutional and Theoretical Economics" 1994, vol. 150(4), s. 609-624). W związku z powyższym, dla jasności wywodu pojęcie „instytucji” będzie w niniejszym opracowaniu używane wyłącznie w odniesieniu do zasad, a pochodzące z prawa UE sformułowanie „instytucja kredytowa” zostanie całkowicie zastąpione terminem „bank”. 
badawczego $\mathrm{w}$ takich ramach pojęciowych nie oznacza jednak ścisłego podążania za wytycznymi neoinstytucjonalizmu; będą one wykorzystane tam, gdzie ten aparat pojęciowy i metodyczny będzie stanowił adekwatne zaplecze koncepcyjne dla analizy przekształceń systemu gwarantowania depozytów w UE i jego obecnej struktury.

\section{Możliwe ścieżki reformy schematów gwarantowania depozytów w UE}

Teoretycznie w ramach unii bankowej możliwe były trzy konstrukcje systemu gwarantowania depozytów: całkowicie wspólny schemat gwarancyjny, funkcjonujący we wszystkich państwach członkowskich UE według zupełnie jednolitych zasad, uzupełnienie systemu krajowych ${ }^{3}$ schematów o dodatkowy funkcjonujący na poziomie unijnym oraz modyfikacja zasad rządzących krajowymi schematami w kierunku zacieśnienia ich współpracy i pewnego ujednolicenia reguł. Początkowo wydawało się, że Komisja Europejska zmierza ku pierwszemu rozwiązaniu ${ }^{4}$, ale dyrektywa z kwietnia 2014 r. ${ }^{5}$ rysuje system mieszczący się w trzecim modelu. Tym ważniejsza wydaje się teoretyczna analiza możliwych rozwiązań i stwierdzenie, czy i w jakim stopniu geneza przeprowadzanej reformy wpłynęły na kształt przyjętego modelu.

Całkowite zastąpienie istniejących krajowych schematów ochrony depozytów jednym wspólnym systemem unijnym należy uznać za najbardziej ambitne rozwiązanie; zdaniem niektórych - było również idealne ${ }^{6}$. Niewątpliwie miało ono największy potencjał w wyeliminowaniu arbitrażu regulacyjnego pomiędzy państwami członkowskimi UE i stanowiło znaczący krok w dalszym pogłębianiu integracji europejskiej. Ponadto, miałoby przyczynić się do oszczędności w kosztach administracyjnych rzędu $40 \mathrm{mln}$ euro rocznie ${ }^{7}$. Taki model spotkał się jednak ze zdecydowanym oporem ze strony państw członkowskich. Oficjalnie podnoszono legalistyczne argumenty

3 Termin „krajowy” jest w niniejszym opracowaniu używany w pochodzącym $\mathrm{z}$ terminologii prawa UE znaczeniu: „właściwy państwu/-om członkowskiemu/-im”.

4 Komisarz UE ds. walutowych Olli Rehn podczas posiedzenia komisji Parlamentu Europejskiego w poniedziałek, 3.09.2012 r., stwierdził: „Osobiście uważam, że kluczowe jest, abyśmy stworzyli jednolity system, w którym mamy wspólny mechanizm nadzoru i elementy drugiego etapu (unii bankowej): wspólny system gwarantowania depozytów oraz fundusz upadłościowy, obejmujące te same banki i kraje" (Polska Agencja Prasowa, UE: wspólny nadzór bankowy tylko z gwarancjami, http://www.lex.pl/czytaj/-/ artykul/ue-wspolny-nadzor-bankowy-tylko-z-gwarancjami, dostęp 19.03.2015).

5 Dyrektywa Parlamentu Europejskiego i Rady 2014/49/UE z dnia 16 kwietnia 2014 r. w sprawie systemów gwarancji depozytów Dz. Urz. UE L 173 z 12.06.2014 r.; dalej: Dyrektywa.

6 T. Bosly, D. Verhagen, Deposit guarantee schemes in the Banking Union, http://lexology.com/library/detail.aspx?g=9dd1cc6b-3a22-4093-9264-9288b4d17ef0, dostęp 15.02.2015.

7 Ibidem. 
naruszenia zasad subsydiarności i proporcjonalności oraz braku umocowania w traktatach konstytuujących UE'; projekt został odrzucony.

Podobny los spotkał również nieco mniej ambitną wizję uzupełnienia sieci krajowych schematów gwarancyjnych o dodatkowy unijny ${ }^{9}$. Wprawdzie w tym wypadku w grę wchodziły też operacyjno-techniczne trudności w zaprojektowaniu mechanizmu przeniesienia części środków z systemów krajowych do ponadnarodowego i regulacji przynależności banku do odpowiedniego systemu. Z jednej bowiem strony, przeniesienie dotychczas zgromadzonych w schemacie krajowym składek banku mającego uczestniczyć w unijnym systemie ochrony depozytów znacząco osłabiłoby ten krajowy (zwłaszcza gdyby do ustalenia właściwości unijnego schematu zastosowano kryterium systemowej istotności). Z drugiej zaś, przedłużone pozostawienie ich w systemie krajowym oddalałoby moment osiągnięcia funkcjonalnej sprawności i zdolności do reakcji przez nowy system unijny. Nie są to jednak problemy niemożliwe do rozwiązania ${ }^{10}$, a przy całkowitej harmonizacji parametrów działania i poziomu ochrony możliwe byłoby wyeliminowanie arbitrażu regulacyjnego ${ }^{11}$.

Przyjęta formuła sieci krajowych schematów gwarancyjnych, wyposażonych w możliwość udzielania sobie pożyczek, zaskakuje skromnością na tle celów stawianych unii bankowej. W procesach integracyjnych w UE nie może przecież uzurpować sobie roli porównywalnej z modelem któregokolwiek z unijnych systemów. Ponadto, jej zdolność do redukcji wewnątrzunijnej konkurencji o ściągnięcie jak największych środków do własnego, lokalnego systemu finansowego zależy od szczegółów konstrukcji; sam model nie zmienia nic w tym zakresie. Identycznie jest $\mathrm{z}$ efektywnością w wypełnianiu podstawowych funkcji systemu gwarantowania depozytów, co skłania do poszukiwania powodów, stojących za jego wyborem poza jego charakterystyką. Analiza kontekstu historycznego, która w ramach neoinstytucjonalnej platformy

8 Traktat o Unii Europejskiej (wersja skonsolidowana: Dz. Urz. UE C 326 z 26.10.2012 r.) i Traktat o funkcjonowaniu Unii Europejskiej (wersja skonsolidowana: Dz. Urz. UE C 326 z 26.10.2012 r.).

9 Taki model odwzorowywałby rozwiązanie przyjęte w zakresie najwcześniej określonej architektury nadzoru - dzielonego między Europejski Bank Centralny (w odniesieniu do banków systemowo istotnych) i krajowe właściwe organy (wobec pozostałych).

10 Warte rozważenia byłoby pozostawienie środków w systemie krajowym do czasu skompensowania wpłatami ex post od pozostałych uczestników lokalnego rynku jego zmienionych parametrów. Alternatywnie, przeniesienie środków do schematu ponadnarodowego można by mitygować gwarancjami dla systemu krajowego wsparcia, w razie zajścia na rynku bankowym państwa członkowskiego zaburzeń, skutkujących roszczeniami przekraczającymi fundusze lokalnego gwaranta. (O. Dzilińska, Elementy unii bankowej jako mechanizmy zmierzające do internalizacji kosztów kryzysu sektora bankowego, w: Oblicza społeczeństwa obywatelskiego. Państwo. Gospodarka. Świat, red. J. Osiński, J.Z. Popławska, Oficyna Wydawnicza SGH, Warszawa 2014, s. 215-216).

${ }^{11}$ Przy niejednolitych parametrach mogłoby jednak dojść do przepływu środków do banków objętych schematem o wyższym lub lepiej skonstruowanym ubezpieczeniu depozytów, co mogłoby doprowadzić do zmian udziałów w rynku. 
badawczej powinna zmierzać do identyfikacji sekwencji zdarzeń, które wywarły określony wpływ na kształt konkretnych rozwiązań instytucjonalnych (path dependence $\left.{ }^{12}\right)$, oferuje takie możliwości.

U źródeł reformy systemu finansowego UE i projektu unii bankowej leży światowy kryzys finansowy 2007+, co zresztą bardzo dobrze wpisuje się w historię powstawania systemów gwarantowania depozytów ${ }^{13}$. W UE kryzys ten przekształcił się z bankowego w zadłużeniowy, który z kolei znów uderzył w system finansowy przez nagle uznane za aktywa toksyczne obligacje niektórych państw członkowskich (Portugalia, Irlandia, Włochy, Grecja, Hiszpania - PIIGS). Jako że próby działań naprawczych podejmowanych lokalnie przez rządy PIIGS okazały się nieskuteczne (także ze względu na związaną z przynależnością do strefy euro niemożność reakcji w zakresie polityki monetarnej), konieczna stała się interwencja na poziomie unijnym. Jej koszty w znacznej mierze obciążyły największego płatnika netto do budżetu UE - Niemcy, wywołując w społeczeństwie niemieckim opór (aż do zakwestionowania konstytucyjności środków pomocowych ${ }^{14}$ ). Mogło to zrodzić obawy o równowagę w „uwspólnieniu” ryzyka w ramach unii bankowej, w szczególności - o ponoszenie kosztów zaburzeń w systemach bankowych innych państw członkowskich, postrzegane nie jako działanie na rzecz zwiększenia stabilności finansowej w UE, lecz jako finansowanie cudzej „jazdy na gapę". Państwa członkowskie spoza strefy euro również nie wykazywały entuzjazmu wobec projektu unii bankowej i wspólnego systemu gwarantowania depozytów, co wynikało m.in. z obaw, że ich wpływ na decyzje podejmowane w ramach unii bankowej będzie znikomy ${ }^{15}$.

Podsumowując, trzeba zwrócić uwagę na dwa aspekty reformy systemu gwarantowania depozytów w UE. Po pierwsze, zrezygnowano z modelu najlepiej odpowiadającego jej explicite wskazywanym celom: eliminacji arbitrażu regulacyjnego i pogłębianiu procesu integracji ${ }^{16}$. Po drugie, przyczyny takiego wyboru należy upatrywać nie w okolicznościach reformy, lecz raczej w określonej ścieżce rozwoju

12 Funkcjonująca w naukach politycznych koncepcja, że proces kształtowania się instytucji jest wynikiem wystąpienia w przeszłości określonego ciągu zdarzeń, z których część może mieć zupełnie losowy charakter, np. ustalony w XIX w. odstęp między szynami kolejowymi. Szerzej nt. pojęcia path dependence: S.E. Page, Path Dependency, "Quarterly Journal of Political Science" 2006, vol. 1, s. 87-115.

13 A. Stelmach, Geneza i uwarunkowania tworzenia systemów ochrony depozytów, w: Współczesny system bankowy. Ujęcie instytucjonalne, red. J. Świderska, Difin, Warszawa 2013, s. 27.

14 T. Durden, Lawsuit Contesting Greek Bailout To Be Heard By German Constitutional Court Imminently, http://www.prisonplanet.com/lawsuit-contesting-greek-bailout-to-be-heard-by-german-constitutional-court-imminently.html, dostęp: 19.03.2015.

${ }_{15}$ M. Samcik, Do unii bankowej prędko nie dojdzie, http://www.obserwatorfinansowy.pl/tematyka/bankowosc/do-unii-bankowej-predko-nie-dojdzie/, dostęp: 19.03.2015.

$16 \mathrm{~W}$ odniesieniu do zdolności do internalizacji kosztów kryzysu finansowego w sektorze decydujące są szczegóły architektury systemu, w tym przede wszystkim - wysokość funduszu w dyspozycji schematu gwarantowania depozytów. 
instytucjonalnego UE. W tej ostatniej mieszczą się nie tylko ograniczenia, jakie na prawodawcę unijnego nakłada jego wcześniejsza aktywność legislacyjna (m.in. różnicująca państwa członkowskie co do zakresu praw i obowiązków ze względu na przynależność lub nie do strefy euro - niezależnie od faktu, że miała ona zależeć od wypełniania przez pewien okres zestawu obiektywnych kryteriów), lecz również sam traktatowy mandat UE, wyznaczony przez kompromis między integracją a zachowywaniem suwerenności państw członkowskich. W dalszym rozrachunku, o niemożności osiągnięcia konsensu w stosunku do postępu integracji zadecydowały więc wbudowane w instytucje UE granice integracji ${ }^{17}$.

\section{Ukształtowanie modelu unijnego systemu ochrony depozytów}

Konstrukcja każdego systemu gwarantowania depozytów wymaga określenia kilku kluczowych aspektów: zakresu przedmiotowego, podmiotowego i charakteru uczestnictwa, sposobu finansowania i zakresu działania oraz poziomu ochrony. Sposób rozstrzygnięcia tych kwestii może zadecydować o zdolności systemu do realizacji podstawowych funkcji, dla których został powołany: wzmacniania zaufania do systemu bankowego oraz obniżania ryzyka systemowego powstania i rozprzestrzeniania się paniki w razie upadłości banku przez zapewnienie ochrony przed jej skutkami klientom banku bankruta.

Zgodnie z art. 4 ust. 3 dyrektywy, prowadzenie działalności bankowej w $\mathrm{UE}^{18}$, w szczególności przyjmowanie depozytów, bez uczestnictwa w urzędowo uznanym schemacie gwarantowania depozytów jest nielegalne. Unijny prawodawca nakłada więc na wszystkie banki obowiązek, którego spełnienie obwarowane jest licznymi warunkami. Uznane schematy gwarantowania depozytów są bowiem tymi, które realizują model określony w dyrektywie. Taka konstrukcja ma zapewnić określony standard ochrony we wszystkich państwach członkowskich UE, ale bynajmniej nie wszystkim klientom banków. Na podstawie art. 5 ust. 1 dyrektywy, z określonych w niej gwarancji wyłączone są bowiem nie tylko fundusze własne, dłużne papiery wartościowe wyemitowane przez bank, zobowiązania wynikające z weksli akceptowanych i weksli własnych czy

17 Postrzeganie „uwspólniania” systemu jako zamachu obcych na środki należne obywatelom danego państwa członkowskiego jest również ich konsekwencją i jednocześnie przejawem.

${ }_{18}$ Na podstawie zezwolenia udzielonego zgodnie z art. 8 dyrektywy Parlamentu Europejskiego i Rady 2013/36/UE z dnia 26 czerwca 2013 r. w sprawie warunków dopuszczenia instytucji kredytowych do działalności oraz nadzoru ostrożnościowego nad instytucjami kredytowymi i firmami inwestycyjnymi, zmieniającej dyrektywę 2002/87/WE i uchylającej dyrektywy 2006/48/WE oraz 2006/49/WE (Dz. Urz. UE L 176 z 27.03.2013 r.). 
depozyty wynikające z transakcji, w związku z którymi doszło do skazania z powodu prania pieniędzy lub takie, których posiadacze nie zostali zidentyfikowani, lecz również depozyty własne innych profesjonalnych uczestników rynku finansowego (banków, przedsiębiorstw inwestycyjnych, zakładów ubezpieczeń i reasekuracji, przedsiębiorstw zbiorowego inwestowania, funduszy rentowych i emerytalnych itd.) oraz organów władzy publicznej. Ochronie mają więc podlegać tylko środki powierzone bankom przez klientów, którzy nie posiadają zasobów i narzędzi (w tym informacji, kompetencji i czasu) do profesjonalnej oceny ryzyka banku. Taka konstrukcja, z jednej strony, służy niwelowaniu skutków asymetrii informacji, jaką obarczony jest system finansowy ${ }^{19}$, a z drugiej - nie zwiększa pokusy nadużycia (moral hazard) po stronie tych uczestników systemu finansowego, którzy mogą i powinni sprzyjać efektywności rynku swoim profesjonalnym osądem (przez wybór banków, których zarządzanie i kondycja same w sobie stanowią wystarczającą gwarancję bezpieczeństwa powierzonych im środków). Pozostawiona w dyspozycji państw członkowskich przez art. 5 ust. 2 dyrektywy możliwość włączenia do systemu gwarancji depozytów indywidualnych systemów emerytalnych i pracowniczych systemów emerytalnych małych lub średnich przedsiębiorstw oraz depozytów władz lokalnych o budżecie rocznym nieprzekraczającym 500 tys. euro, nie narusza tej zasady. Wspomniana opcja narodowa dotyczy przecież de facto klientów, którym również trudno przypisać zasoby i możliwości analizy, jakimi dysponują duzi profesjonalni uczestnicy rynku finansowego.

Schematy gwarantowania depozytów zwykle są finansowane ze składek banków działających na rynku objętym ich gwarancją, przy czym funkcjonują dwa podstawowe modele: ex ante i ex post $t^{20}$. Model systemu przyjęty w dyrektywie opiera się na składkach wnoszonych przez członków co najmniej corocznie, chociaż nie wyklucza finansowania z innych źródeł. Ponadto, art. 10 ust. 8 dyrektywy wprost przewiduje konieczność wniesienia przez członków składek nadzwyczajnych w sytuacji, gdy środki finansowe schematu gwarancji depozytów okażą się niewystarczające do dokonania wypłat deponentom, których depozyty stały się niedostępne, co częściowo mityguje ryzyko związane z ustaleniem docelowego pułapu środków w dyspozycji systemu gwarantowania depozytów. Formuła przyjęta przez prawodawcę unijnego wykorzystuje więc podstawowe zalety, przyjętego jako zasada ogólna, finansowania ex ante - mniejszą pokusę nadużycia ${ }^{21} \mathrm{i}$ brak wyraźnej procykliczności - dodatkowo

19 A. Jurkowska-Zeidler, Bezpieczeństwo rynku finansowego w świetle prawa Unii Europejskiej, Wolters Kluwer, Warszawa 2008, s. 179.

${ }^{20}$ B. Zdanowicz, Podstawowe dylematy i kryteria wyboru formuly systemu gwarantowania depozytów w świetle teorii i doświadczeń międzynarodowych, „Bezpieczny Bank” 2007, nr 1(34), s. 3-231.

${ }^{21}$ Finansowanie ex post wydaje się zawierać inherentną zachętę do „jazdy na gapę”. Można je bowiem skonstruować $\mathrm{w}$ dwóch wariantach: płatności przez zagrożony bank lub składki pozostałych instytucji uczestniczących w systemie. W pierwszym wariancie dodatkowe obciążenie banku wychodzącego 
redukując presję na wsparcie systemu finansowego środkami publicznymi przez uzupełnienie jej w sytuacjach szczególnych o dopłaty ex post, co wydaje się najwłaściwszym rozwiązaniem ${ }^{22}$.

Przede wszystkim jednak, art. 13 dyrektywy nakazuje powiązanie składek obciążających poszczególne banki z poziomem ryzyka związanego z ich działalnością i wielkością jego gwarantowanych depozytów. Taka konstrukcja odzwierciedla ubezpieczeniową rolę systemu gwarantowania depozytów: im wyższa tolerancja banku dla ponoszenia ryzyka, tym większy koszt obowiązkowego ubezpieczenia środków jego deponentów, a sankcjonowanie bardziej ryzykownych modeli działalności wyższą składką, może dalej redukować pokusę nadużycia związaną z istnieniem gwarancji depozytów ${ }^{23}$. Co więcej, badania wskazują, że uwzględnienie poziomu ryzyka w wysokości składek może uczynić system antycyklicznym ${ }^{24}$. Na tym etapie nie ma jednak pewności, że w wydanych na podstawie art. 13 ust. 3 dyrektywy wytycznych Europejskiego Urzędu Nadzoru Bankowego zostanie zastosowany algorytm analogiczny do rozważanego przez G.G. Pennacchiego. Nie wiadomo również, czy i ewentualnie w jaki sposób w konstrukcji składki uwzględnione zostaną koszty bankructwa lub likwidacji poszczególnych banków, co ma znaczenie wobec faktu, że system gwarantowania depozytów ma także uczestniczyć w finansowaniu restrukturyzacji i uporządkowanej likwidacji banków zgodnie z odpowiednimi przepisami ${ }^{25}$.

z kryzysu może spowolnić ten proces, a odłożenie płatności do czasu, kiedy instytucja odzyska dobrą kondycję, grozi przeniesieniem kosztów wyprowadzania jej z sytuacji kryzysowej na podatników. Co więcej, w sposób naturalny pojawi się tendencja do coraz dalszego odraczania momentu płatności. W drugim wariancie natomiast zwiększanie „apetytu” na ryzyko w pogoni za krótkoterminowymi zyskami jest niejako premiowane 1) brakiem jakichkolwiek płatności na rzecz systemu i 2) przeniesieniem kosztów sytuacji kryzysowej na jego pozostałych uczestników, O. Dzilińska, op.cit., s. 213. Finansowanie ex ante nie jest obarczone podobnym w zakresie kierunku oddziaływania układem zachęt.

22 Ibidem, s. 214.

Ocena dotyczy samej formuły; nie uwzględnia jednak szczegółów przyjętego w art. 10 ust. 8 dyrektywy mechanizmu, w szczególności - ograniczenia składek nadzwyczajnych do 0,5\% wartości depozytów gwarantowanych zgromadzonych przez poszczególnych członków systemu w roku kalendarzowym.

${ }^{23}$ Niezależnie od osłabienia potrzeby zapewnienia deponentów o bezpieczeństwie powierzanych bankowi środków, a z nią monitoringu banku przez deponentów, bank będzie zniechęcany do podejmowania bardziej ryzykownej działalności wyższą składką.

${ }_{24}$ G.G. Pennacchi, Risk-based capital standards, deposit insurance, and procyclicality, "Journal of Financial Intermediation" 2005, vol. 14, no. 4, s. 432-465.

Konkluzja opiera się na założeniu, że algorytm kalkulacji składki na obowiązkowy schemat ochrony depozytów wykorzystuje średnie ruchome, obejmujące dane za kilka kolejnych lat, co pozwala zmniejszyć różnice w poziomach składki obciążającej dany bank w różnych fazach cyklu koniunkturalnego, rozkładając zwiększone ryzyko okresu recesji także na lata dobrej koniunktury. Wprawdzie takie międzyokresowe wyrównanie składki skutkuje wzrostem jej średniego poziomu (ze względu na inherentną niepewność co do przyszłości), ale wydaje się, że wobec relatywnego zmniejszenia obciążenia w kryzysie korzyści przeważają, także z perspektywy pojedynczego banku.

${ }^{25}$ Dyrektywa Parlamentu Europejskiego i Rady 2014/59/UE z dnia 15 maja 2014 r. ustanawiająca ramy na potrzeby prowadzenia działań naprawczych oraz restrukturyzacji i uporządkowanej likwidacji w odniesieniu do instytucji kredytowych i firm inwestycyjnych oraz zmieniająca dyrektywę Rady 82/891/EWG 
Poziom ochrony zapewniany przez systemy gwarancji depozytów określa wiele czynników. Za podstawowy można uznać górną granicę gwarancji - na podstawie art. 6 ust. 1 dyrektywy jest to 100 tys. euro lub ich równowartość w walucie krajowej $^{26}$. Zgodnie z art. 7 ust. 1 dyrektywy kwota ta ma zastosowanie do wszystkich depozytów jednego deponenta w jednym banku, niezależnie od ich liczby, waluty i miejsca ulokowania w UE. W wypadku rachunków wspólnych, wysokość gwarancji ma zastosowanie do każdego z posiadaczy osobno ${ }^{27}$. Kwota wydaje się więc na tyle wysoka, żeby zapewnić poczucie bezpieczeństwa większości deponentów w $\mathrm{UE}^{28}$, tym bardziej, że jest ona gwarantowana w $100 \%$ i bez koasekuracji ze strony deponentów, a przekraczające ją należności osób fizycznych oraz małych i średnich przedsiębiorstw i tak mają pierwszeństwo w procesie ewentualnej likwidacji banku. Także organizacja wypłaty środków gwarantowanych została skonstruowana tak, by dalej podnosić zaufanie do systemu bankowego. Sam termin wypłaty już obecnie nie może przekraczać 20 dni roboczych, a do 1 stycznia 2024 r. ma być stopniowo skracany do docelowych $7 \mathrm{dni}^{29}$, co de facto likwiduje problem braku dostępu do należnych klientom banku środków, tym bardziej że wypłata nie jest uzależniona od złożenia odpowiedniego wniosku. Dodatkowemu wzmocnieniu poczucia bezpieczeństwa deponentów może służyć określona co do zakresu i formy informacja na temat

i dyrektywy Parlamentu Europejskiego i Rady 2001/24/WE, 2002/47/WE, 2004/25/WE, 2005/56/WE, 2007/36/WE, 2011/35/UE, 2012/30/UE i 2013/36/EU oraz rozporządzenia Parlamentu Europejskiego i Rady (UE) nr 1093/2010 i (UE) nr 648/2012 (Dz. Urz. UE L 173 z 12.06.2014 r.).

${ }^{26}$ Państwa członkowskie mają jednak, na podstawie art. 6 ust. 2 dyrektywy, obowiązek zapewnienia, by depozyty: (1) wynikające z transakcji dotyczących nieruchomości związanych z prywatnymi nieruchomościami mieszkalnymi oraz (2) spełniające cele społeczne określone w prawie krajowym i związane z takimi sytuacjami życiowymi deponenta jak małżeństwo, rozwód, przejście na emeryturę, zwolnienie z pracy, inwalidztwo lub zgon były objęte ochroną powyżej kwoty 100 tys. euro przez okres nie krótszy niż trzy miesiące i nie dłuższy niż 12 miesięcy od uznania lub momentu, kiedy zaistnieje prawna możliwość ich przeniesienia.

${ }^{27}$ Chyba że prawa współposiadaczy do rachunku wynikają z ich udziału w spółce osobowej lub członkostwa w stowarzyszeniu czy podobnym ugrupowaniu niemającym osobowości prawnej, a państwo członkowskie, którego schematem gwarancyjnym objęty jest ich depozyt, zdecydowało skorzystać z przewidzianej w art. 7 ust. 2 dyrektywy opcji narodowej - wówczas środki zgromadzone na takim rachunku traktowane są jako jeden depozyt.

Ponadto, jeśli państwo członkowskie przyjmie takie rozwiązanie, przy ustalaniu kwoty podlegającej wypłacie mogą zostać potrącone (w zakresie określonym odpowiednimi przepisami ustawowymi i umową między deponentem a bankiem) te zobowiązania deponenta wobec banku, które stały się wymagalne najpóźniej w dniu urzeczywistnienia się niedostępności depozytu.

28 Przytaczane są szacunki, wg których podniesienie górnej granicy kwoty gwarantowanej podczas kryzysu finansowego 2007+ zredukowało udział depozytów nieobjętych pełną ochroną, z 12\% ogółu depozytów w UE do zaledwie 5\% (T. Bosly, D. Verhagen, op.cit.).

${ }^{29}$ Za zdarzenie inicjujące procedurę wypłaty uznano niedostępność depozytu zdefiniowaną w art. 2 ust. 1 pkt 8 dyrektywy jako uznaną przez właściwy organ administracji niezdolność banku wypłacenia należnego i wymagalnego depozytu lub wydanie przez sąd z powodów bezpośrednio związanych z sytuacją finansową orzeczenia skutkującego zawieszeniem praw deponentów w zakresie dochodzenia roszczeń wobec banku, uwalniając dochodzenie takich należności od procedur upadłości lub restrukturyzacji banków. 
systemu gwarantowania depozytów, którą banki będą obowiązane przekazywać klientom przed zawarciem umowy o przyjęcie depozytu i co najmniej raz do roku, a w skróconej wersji - na wyciągach z rachunku ${ }^{30}$. Jednocześnie przez ograniczenia nałożone na komunikaty reklamowe ograniczona ma zostać dezinformacja w tym $z_{\text {zakresie }}^{31}$. Zaprojektowany w dyrektywie model wydaje się więc zapewniać nieprofesjonalnym uczestnikom systemu bankowego wielowymiarową ochronę, obejmującą gwarancje uzyskania adekwatnej informacji o jej zakresie, co uprawdopodabnia jej założone funkcjonowanie.

Reforma systemu gwarantowania depozytów rozpoczęta w ramach procesu tworzenia unii bankowej wydaje się niezakończona. Wymierzona we fragmentaryczność schematu ochrony depozytów, sprzyjającą konkurencji między krajowymi systemami i arbitrażowi regulacyjnemu zarówno ze strony banków, jak i ich klientów, rozwiązuje wiele technicznych problemów. Ujednolica w znacznej mierze zakres gwarancji dla deponentów, zapewnia równy dostęp do istotnych informacji, harmonizuje modele działania krajowych schematów i zmniejsza ryzyko, że ich działania ograniczałyby wzajemnie swoją skuteczność. Dzięki temu wzmacnia zaufanie do systemu bankowego. Niemniej jednak ze względu na wbudowane opcje narodowe nie eliminuje ostatecznie ani fragmentaryzacji, ani żadnej ze związanych z nią dysfunkcji, a budowa zaufania między państwami członkowskimi i pogłębianie wspólnego rynku nie będzie możliwe bez skutecznego wyeliminowania arbitrażu regulacyjnego.

W zakresie internalizacji kosztów zaburzeń w sektorze finansowym przyjęty model czyni nawet trzy kroki naprzód: zapewnia we wszystkich państwach członkowskich możliwość nadzwyczajnego dofinansowania systemu gwarancyjnego ex post, stwarza mechanizm pożyczek między krajowymi gwarantami i otwiera możliwość finansowania działań naprawczych, które nierzadko mogą okazać się mniej kosztowne od wypłaty gwarantowanych depozytów. Wątpliwości budzić może jednak kwestia, czy w razie kryzysu zgromadzone w krajowych schematach środki w wysokości odpowiadającej 0,8\% gwarantowanych depozytów, przy wszystkich dodatkowych mechanizmach pozyskiwania nadzwyczajnego finansowania, okażą się wystarczające. Jeśli nie, ochrona okaże się iluzoryczna, schemat nie zrealizuje swoich podstawowych

${ }^{30}$ Zgodnie $\mathrm{z}$ art. 16 ust. 4 dyrektywy, informacje te mają być przekazywane w języku uzgodnionym przez deponenta i bank w monecie otwarcia rachunku lub w języku urzędowym państwa członkowskiego, w którym działa oddział banku, z którym deponent zawarł taką umowę. Analogiczne wymogi, zmierzające do zapewnienia skutecznej komunikacji z deponentem, zostały w art. 8 ust. 7 dyrektywy nałożone również na korespondencję z systemem gwarantowania depozytów.

31 Obejmują one w szczególności wyrażony explicite zakaz stosowania nieograniczonego zakresu gwarancji depozytów. 
funkcji i zaufanie do systemu bankowego zostanie po raz kolejny zachwiane. Gdyby zaś niektóre państwa członkowskie podniosły ów poziom docelowy, w zamiarze wyeliminowania takiej ewentualności, dojdzie do dalszej dezintegracji.

\section{Bibliografia}

Bosly T., Verhagen D., Deposit guarantee schemes in the Banking Union, http://lexology.com/library/detail.aspx?g=9dd1cc6b-3a22-4093-9264-9288b4d17ef0, dostęp 15.02.2015

Durden T., Lawsuit Contesting Greek Bailout To Be Heard By German Constitutional Court Imminently, http://www.prisonplanet.com/lawsuit-contesting-greek-bailout-to-be-heardby-german-constitutional-court-imminently.html, dostęp 19.03.2015.

Dyrektywa Parlamentu Europejskiego i Rady 2014/49/UE z dnia 16 kwietnia 2014 r. w sprawie systemów gwarancji depozytów, Dz. Urz. UE L 173 z 12.06.2014 r.

Dyrektywa Parlamentu Europejskiego i Rady 2013/36/UE z dnia 26 czerwca 2013 r. w sprawie warunków dopuszczenia instytucji kredytowych do działalności oraz nadzoru ostrożnościowego nad instytucjami kredytowymi i firmami inwestycyjnymi, zmieniająca dyrektywę 2002/87/WE i uchylająca dyrektywy 2006/48/WE oraz 2006/49/WE, Dz. Urz. UE L 176 z 27.03.2013 r.

Dyrektywa Parlamentu Europejskiego i Rady 2014/59/UE z dnia 15 maja 2014 r. ustanawiająca ramy na potrzeby prowadzenia działań naprawczych oraz restrukturyzacji i uporządkowanej likwidacji w odniesieniu do instytucji kredytowych i firm inwestycyjnych oraz zmieniająca dyrektywę Rady 82/891/EWG i dyrektywy Parlamentu Europejskiego i Rady 2001/24/WE, 2002/47/WE, 2004/25/WE, 2005/56/WE, 2007/36/WE, 2011/35/UE, 2012/30/UE i 2013/36/EU oraz rozporządzenia Parlamentu Europejskiego i Rady (UE) nr 1093/2010 i (UE) nr 648/2012, Dz. Urz. UE L 173 z 12.06.2014 r.

Dzilińska O., Elementy unii bankowej jako mechanizmy zmierzające do internalizacji kosztów kryzysu sektora bankowego, w: Oblicza społeczeństwa obywatelskiego. Państwo. Gospodarka. Świat, red. J. Osiński, J.Z. Popławska, Oficyna Wydawnicza SGH, Warszawa 2014.

Jurkowska-Zeidler A., Bezpieczeństwo rynku finansowego w świetle prawa Unii Europejskiej, Wolters Kluwer, Warszawa 2008.

North D.C., Institutions, Institutional Change and Economic Performance, Cambridge University Press, Cambridge 1990.

North D.C., Wallis J.J., Integrating Institutional Change and Technical Change in Economic History: A Transaction Cost Approach, "Journal of Institutional and Theoretical Economics" 1994, vol. 150(4).

Page S.E., Path Dependency, "Quarterly Journal of Political Science” 2006, vol. 1.

Pennacchi G.G., Risk-based capital standards, deposit insurance, and procyclicality, "Journal of Financial Intermediation" 2005, vol. 14, no. 4.

Polska Agencja Prasowa, UE: wspólny nadzór bankowy tylko z gwarancjami, http://www.lex. $\mathrm{pl} /$ czytaj/-/artykul/ue-wspolny-nadzor-bankowy-tylko-z-gwarancjami, dostęp 19.03.2015. 
Raport o stabilności systemu finansowego czerwiec 2009 r., Narodowy Bank Polski, red. P. Szpunar, Warszawa 2009.

Samcik M., Do unii bankowej prędko nie dojdzie, http://www.obserwatorfinansowy.pl/tematyka/bankowosc/do-unii-bankowej-predko-nie-dojdzie/, dostęp 19.03.2015.

Stelmach A., Geneza i uwarunkowania tworzenia systemów ochrony depozytów, w: Współczesny system bankowy. Ujęcie instytucjonalne, red. J. Świderska, Difin, Warszawa 2013.

Zdanowicz B., Podstawowe dylematy i kryteria wyboru formuly systemu gwarantowania depozytów w świetle teorii i doświadczeń międzynarodowych, „Bezpieczny Bank” 2007, nr 1(34).

Traktat o Unii Europejskiej wersja skonsolidowana, Dz. Urz. UE C 326 z 26.10.2012 r.

Traktat o funkcjonowaniu Unii Europejskiej wersja skonsolidowana, Dz. Urz. UE C 326 z 26.10.2012 r. 